\title{
Criminology: Some Lines of Flight
}

\section{Julie Berg}

Scottish Centre for Crime and Justice Research, University of Glasgow, UK

\section{Clifford Shearing}

Department of Public Law, University of Cape Town, South Africa; Griffith Institute of Criminology and School of Criminology and Criminal Justice, Griffith University, Australia; School of Criminology, University of Montreal, Canada

\begin{abstract}
The 40th Anniversary Edition of Taylor, Walton and Young's New Criminology, published in 2013, opened with these words: 'The New Criminology was written at a particular time and place, it was a product of 1968 and its aftermath; a world turned upside down'. We are at a similar moment today. Several developments have been, and are turning, our 21 st century world upside down. Among the most profound has been the emergence of a new earth, that the 'Anthropocene' references, and 'cyberspace', a term first used in the 1960s, which James Lovelock has recently termed a 'Novacene', a world that includes both human and artificial intelligences. We live today on an earth that is proving to be very different to the Holocene earth, our home for the past 12,000 years. To appreciate the Novacene one need only think of our 'smart' phones. This world constitutes a novel domain of existence that Castells has conceived of as a terrain of "material arrangements that allow for simultaneity of social practices without territorial contiguity' - a world of sprawling material infrastructures, that has enabled a 'space of flows', through which massive amounts of infor- mation travel. Like the Anthropocene, the Novacene has brought with it novel 'harmscapes', for example, attacks on energy systems. In this paper, we consider how criminology has responded to these harmscapes brought on by these new worlds. We identify 'lines of flight' that are emerging, as these challenges are being met by criminological thinkers who are developing the conceptual trajectories that are shaping 21 st century criminologies.
\end{abstract}

\section{Keywords}

Criminology, criminology foundations, criminological theory, criminology history, New Criminology 
Line of flight: the flight path of something travelling from one place to another.

Collins English Dictionary.

The 40th Anniversary Edition of Taylor, Walton and Young's New Criminology, published in 2013, opened with these words: 'The New Criminology was written at a particular time and place, it was a product of 1968 and its aftermath; a world turned upside down'. We are at a similar moment today.

Several developments have been, and are turning, our $21^{\text {st }}$ century world upside down. Among the most profound has been the emergence of a new earth, that the 'Anthropocene' references, and 'cyberspace', a term first used in the 1960s, which James Lovelock (2019) has recently termed a 'Novacene', a world that includes both human and artificial intelligences. We live today on an earth that is proving to be very different to the Holocene earth, our home for the past 12, 000 years (see for example, Bonneuil \& Fressoz, 2017). David Attenborough (2020, p. 21) has described this receding geological epoch as 'our Garden of Eden' -- an exceptionally short geological era with a temperate climate, that enabled humans, along with many other species, to flourish. To appreciate the dramatic nature of this era shift one need only reflect on Australia's recent wildfires.

Monster firestorms reaching temperatures of over 1, 000 degrees Celsius moved across Australia's landscape in the summer of 2019-2020, consuming forests, burning animals in the billions, and destroying human lives, Australians watched the arrival of a future wildfire world that the climate science had been predicting for some time (Drahos, 2021, p. ix).

To appreciate the Novacene one need only think of our 'smart' phones. This world constitutes a novel domain of existence that Castells (1999, p. 294) has conceived of as a terrain of "material arrangements that allow for simultaneity of social practices without territorial contiguity' -- a world of sprawling material infrastructures, that has enabled a 'space of flows', through which massive amounts of information travel. Like the Anthropocene, the Novacene has brought with it novel 'harmscapes' (Berg \& Shearing, 2018), for example, attacks on energy systems (see for example, Greenberg, 2019).

In this paper we consider how criminology has responded to these harmscapes brought on by these new worlds. We identify 'lines of flight' that are emerging as these challenges are being met by criminological thinkers who are developing the conceptual trajectories that are shaping 21 st century criminologies. 


\section{Criminology's lines of flight}

Criminology, as we know it today, is an Anglo-American enterprise. A crucial moment in the history of contemporary criminology was the emergence, in the late 1700s and the early $1800 \mathrm{~s}$, of a set of institutional arrangements for the governance of security that remain with us today, namely, criminal justice systems, with police as their 'front end' (see Radzinowicz, 1956; Kelling, 1991). These historical roots have shaped who we are and what we do as criminologists - our 'normal science' (Kuhn 2012). At the edges of our enterprise have been criminologists who have questioned this normal paradigm - examples include scholars who have proposed a 'harmology' (Hillyard, 2004), 'penal abolitionists' (Ruggiero, 2010), and proponents of 'justice reinvestment' (Clear, 2011). More broadly are thinkers such as Bruno Latour, who have challenged the Durkheimian paradigm of a sui generis social world, as embraced by criminology, that excludes non-human 'actants' ${ }^{1}$ In other words, there has been a number of developments challenging the foundational paradigms that have been so influential in shaping criminology. These foundational paradigms include both the Hobbesian normative political project that has promoted the provision of security governance by states, albeit with sometimes significant 'third-party' support (Mazerolle and Ransley 2005); as well as the Durkheimian lens, mentioned, that established a 'social world' as a distinct terrain of scholarly engagements, distinct from engagements with the 'natural world'.

We turn now to identify some of the lines of flight, within criminology, which are challenging these foundational paradigms in the context of new harmscapes, and which also serves to introduce a more extensive enquiry (Berg \& Shearing, forthcoming).

\section{Flight Line 1: Diverse knowledges}

Criminology, as we have suggested, is deeply entangled with Western-centric and Northern ways of thinking (see for example, Agozino, 2004; Cunneen, 2011; Lee \& Laidler, 2013; Moosavi, 2019). This framing, it is being argued, has fundamentally shaped, and in doing so, curtailed criminological thinking. Indeed, Kitossa (2020, p. 9) has gone as far as to provocatively state, with reference to the influence of Hobbesian thinking, that 'the thesis that the state-as-Leviathan is a neutral arbiter preventing a war of all against all' has introduced into criminology's foundational framings a 'racist statecraft'. An implication of this line of flight is that if criminology is to effectively engage $21^{\text {st }}$ century realities it must pay far more attention than it has to diverse knowledges that challenge established 'ways of seeing' (Smith, 1987). By way of example, to move to one of criminology's contemporary edges, in 
managing wildfires and their harmscapes, an argument being advanced is that indigenous knowledges and practices should be accorded greater salience (see for example, Mullins, 2020; Carbon Market Institute, 2020).

Concerns about the exclusion of diverse knowledges have emerged as a pervasive feature of contemporary criminological thought. This is reflected in the emergence of a major body of thought focused on shifting thinking and developments emanating from the 'Global South', from the 'periphery' and the 'semi-periphery' (Lee \& Laidler, 2013; Medina, 2011; Moosavi, 2019), to the centre of the criminological stage. These have included: a 'counter-colonial criminology' (Agozino, 2003, 2020; Kitossa, 2012); a 'neo-colonial' criminology (Deckert, 2014); an ‘indigenous' criminology (Cunneen \& Tauri, 2016; Tauri, 2017); a 'southern' criminology and a 'green southern' criminology (Carrington, Hogg \& Sozzo, 2016; Carrington et al., 2018, Carrington, Dixon, Fonseca, Goyes, Liu \& Zysman, 2019; Carrington, Hogg, Scott, Sozzo \& Walters, 2019; Goyes, 2019); a 'postcolonial' criminology (Cunneen, 2011; Medina, 2011); along with more regionally-based criminologies, such as Asian (Lee \& Laidler, 2013; Liu, 2009, Liu et al., 2013; Liu, 2017; Liu et al., 2017), African (Alemika, 2020; Chukwuma, 2011; Dixon, 2001; Dixon, 2004; Ebbe, 2011; van Zyl Smit, 1999), Latin American (Del Olmo, 1999; Escobar, 2011; Heskia, 2011; Juarez \& Solares, 2011; Rodrigues, 2011; Schulte-Bockholt, 2012), as well as a criminology of the Arab world (Ouassini \& Ouassini, 2020).

This knowledge-focused line of flight has actively sought to decouple criminological thinking and practice from its Western-centric conceptual roots. The hope is that this will produce beneficial shifts in practices, in relation to emerging harmscapes. For example, better ways of preventing and responding to wildfires.

\section{Flight Line 2: Pluralism}

Another influential line of flight within criminology, and cognate disciplines, has been arguments that have argued for the value of engaging conceptually with plural or polycentric ordering arrangements (Loader, 2000). There has been considerable empirical criminological work, over the past several decades, that has challenged the contemporary relevance of the long-held Hobbesian framing both with respect to the empirical reality of, and the normative advantages of, state-centric governance.

While this theme has been closely associated with critical scholarship arising out of the Global South, this questioning of Hobbesian thinking has been a significant line of flight within criminology more generally (Garland, 1996). As Spitzer and Scull (1977) argued over 
four decades ago, private governance, along with 'private governments' (Macauley 1986), has long been a reality to which criminology has paid scant attention. Similar arguments have been made by a host of critical legal scholars (for example, Galanter, 1981; and Kennedy \& Klare, 1984) as well as a good number of criminologists working at the edges of the criminological stage (for example, Baker, 2008) -- developments that have led to a long, and continuing, journey that recognises the diversity of security governance assemblages -for example, Brodeur's (2010) 'policing web', as well as Jones \& Newburn (2006), Crawford et al. (2005), Stenning (2009), van Sluis et al. (2011). These 'nodal' and 'polycentric' conceptions of security governance recognise, and are nested within, a broader recognition of alternative ordering systems, under signs such as 'pluralism', that has long included both state and non-state auspices and providers across a variety of scholarly terrains that include anthropology, law and economics. An example is the research of Elinor and Vincent Ostrom -- work that led to Elinor being awarded the Nobel Prize in Economics in 2009.

Within criminology -- a research domain that has, from its earliest beginnings, recognised plural governance -- is the Novacene. Within cyber studies, scholars have been active in exploring plural governance configurations (examples include, Button, 2020; Chang et al., 2018; Dupont, 2018; Jewkes, 2003; Wall, 2007). This recognition of, and associated mapping of governance assemblages, has done much to redirect thinking to polycentric realities, within criminology. This is something that Simon (2007) drew attention to in his 'governing through crime' critical analysis, as did Garland and Sparks (2000) in their admonition to think 'beyond the state'. Mariana Valverde (in a 2013 lecture, entitled 'Time and Space in the Governance of Crime and Security', shared in a personal communication) spelt out a methodological stance to be adopted in exploring polycentric forms of governance, a stance that emphasizes the importance of undertaking research that explicitly draws attention to the diversity of practices that have, and are, shaping and reshaping policing.

While the theories and histories of security that we now have are certainly useful to criminology, it may be time to move to a different type of project, one that instead of focusing on security as a noun, a thing - a choice that inevitably leads into normative discussions about good security vs bad security — turns the gaze not on a single word or a concept but rather on the very wide variety of activities, practices that are being carried out under the name of 'security'. 
A central theme of these analyses has been the argument that polycentric forms of governance are associated with, and are particularly well suited to, the governance of emerging harmscapes. There has been considerable empirical criminological work over the past decades which has exposed the Hobbesian myth of a state-centric world of governance - particularly from Global South perspectives where in some respects this Hobbesian framing has either been perversely applied (e.g. colonialism) or never had much traction at all. But even within the heart of the Anglosphere, criminology has long recognised that the Hobbesian dream was always a myth (Garland, 1996). What this train of research and thinking has recognised is that engaging with new harmscapes requires a conceptual engagement with the realities of a pluralised or 'polycentric' world of both an intersection of harms, or harmscapes, and interacting, orderings, and governance processes, that the term 'plural governance' references (Shearing, 2006).

\section{Flight Line 3: Harm-focused}

This brings us to our third line of flight. In seeking to move beyond a 'governing though crime' paradigm alone, Hillyard (2004) and Tombs, (see for example, Hillyard and Tombs 2007) have, as we have suggested, advocated a harm-focused conceptual turn -- one that understands criminology not simply as 'crime-ology' but as a 'harm-ology'. This broadens the criminological horizon beyond harms, largely interpersonal, that 'crime' typically references. These developments have encouraged the inclusion of a broader set of harms within criminology's ambit. This, incidentally, has led some criminologists to express concerns that such a broadening might be moving criminology beyond a crime anchorage. This might lead to criminology losing its integrity and being swallowed up by other enterprises, such as regulatory studies (Valverde, 2014; Floyd, 2015).

As with other lines of flight this line of flight has many facets. A line of critique that has featured in the harm-focused flight line has involved making explicit a set of deeply entrench conceptual leanings that Kitossa (2020) has provocatively identified as constituting an 'authoritarian criminology' - that has synergies with the 'racist statecraft' mentioned earlier. This line of flight is associated with concerns expressed about practices such as racial profiling, and discriminatory practices more generally. This theme, though typically expressed in less strident terms, has been a pervasive analytic theme within criminology for decades. A significant variant of this theme, that focuses on the institutions of criminal justice and a governing through crime modality, is one that Kitossa (2020) has conceived of 
in terms of a systemic set of tendencies that devalue populations -- 'devalued populations'. This has been a multi-faceted line of flight that includes concerns about the harmful impacts of incarceration (for example, Clear, 2007), 'overcriminalization' (Haugh, 2015), and racism. This set of concerns, which is often tied back to criminology's colonial heritage, is finding expression today in the 'black lives matter' movement as well as regionally specific developments such as the South African 'Rhodes must fall' movement (for examples, see Agozino, 2004: Cunneen, 2011; Cunneen and Tauri, 2016).

A persistent theme that threads along this line of flight has been a concern that a pervading impact of criminal justice arrangements, and the sense-making that takes place in and through them, has been the essentialising of the victim-offender dichotomy, with its blame-focused agenda (Pemberton, 2007; Tombs, 2018) -- a 'way of seeing', as Smith (1987) has noted, is always also a 'way of not seeing' (see James Boyd White (1984) for a wonderfully lucid, and meticulously documented analysis of this theme through a literary lens). This particular critical theme draws attention to the way in which normatively-loaded ways of seeing are embedded within, disguised by, seemingly non-normative distinctions that can, and do, have very real material implications, for example, in the distinction between 'natural' and 'social' worlds and 'natural' and 'social' sciences (see for example, Braithwaite, 2000 for a discussion of this within a criminology ambit and Latour across his entire oeuvre, for instance, 'We Have Never Been Modern', 1993). This line of critique, as we have hinted in our reference to Latour's conception of things as 'actants', is crucial to understandings of the management of harmscapes in both the Anthropocene and the Novacene, and the deep entanglement of humans and non-humans that is an essential feature of both these worlds.

A significant development in this line of flight has been the emergence of 'green criminology', and more recently 'climate change criminology', as a criminological response to the harms associated with the Anthropocene (Lynch, 1990; South, 1998; White, 2018). Interestingly, much of this, and related, work has sought to increase the relevance of the criminal justice paradigm by seeking to 'crime-ize' (Berg \& Shearing, 2018) environmental harms. An example, is the arguments that have been advanced in favour of recognizing some environmental harms as constituting the crime of 'ecocide' (White, 2018a). This perspective has sought actively to engage with the impacts of global harms referenced by the decolonised and southern criminology approaches outlined earlier by drawing attention to the power disparities and social injustices of neo-colonial resource exploitation within the Global South (White, 2018; Goyes, 2019). 
As we have noted, a significant feature of these environmental developments has been a Latourian sensibility that acknowledges the role of non-humans as agentic 'actants' within human-thing assemblages, thereby challenging Durkheim's conception of social worlds as sui generis realities. This acknowledgement 'that human beings are merely one component of complex ecosystems' recognizes the interconnectedness and entanglements of all living entities in ways that have directly challenged the established focus within criminology on human-to-human harms (White, 2011, p. 34; see also Brisman \& South, 2018; White \& Heckenberg, 2014). This shift from an exclusive criminological focus on human-to-human harms to one that includes human-to-thing, and thing-to-human harms resonates with broader thinking on the interconnectedness of humans and non-humans, which is the subject of our next line of flight.

\section{Flight Line 4: Posthumanism}

Our final line of flight is one that fully engages with the cyberworld and its inhabitants. These explorations have often taken place under the sign 'posthuman', in recognition of the emergence of a hybrid world of humans and things made up of novel assemblages - a related term that is often utilized to recognise these assemblages is 'cyborg'. In this thinking, entanglements are recognised as a fundamental reality of life, in the words of Harrington and Shearing (2017, pp. 16, 17, 20, 52) in relation to the Anthropocene:

We have discovered the unthinkable: how we act matters not just for us but for Earth itself. We are, to our surprise, deeply and irrevocably entangled .... we are entangled in a complex set of assemblages — one set of interlinked things among many .... [an] entanglement of nature and society ... [human as] being-in-relation ... enmeshed with a diversity of beings, things, histories and technologies.

It is not that our entanglements are novel, this has always been our reality. Rather what is novel is our emerging recognition of our entanglements -- in Latour's (1993) words -- 'we have never been modern'. In other words, 'that the separation of the social and natural worlds (that has been so central to modernity) constitutes a flawed illusion' (Shearing, 2015).

Although the concept of 'posthumanism', remains underdeveloped within criminology, there has nevertheless been a long engagement within criminology with the role of 'things' in shaping human behaviour, such as, for instance situational crime prevention and 
its concerns with 'designing out' crime (Clarke, 1997; Felson, 1998). The criminological engagement with 'things' that posthumanism and cyberspace references and that we have canvassed, is building on well-established human-thing foundations. More recent developments are constituting emerging pathways within criminology that invite a fuller engagement with things as 'actants'. For instance, Van der Wagen and Pieters (2015, p. 578; 2020) have explored the role of 'botnets' as non-human agents and in doing so they acknowledge 'the rather anthropocentric theoretical repertoire of criminology' that we have briefly referenced here. A repertoire that is embedded in a deep and pervasive hubris that we humans are finally, after a long history of recognition of its dangers (Bonneuil \& Fressoz, 2017; see also Wallace-Wells, 2019), beginning to recognise, and that we are hopefully leaving behind.

\section{Conclusion}

What we have seen in this brief flagging exercise is that the foundations for a criminological engagement with shifting circumstances already exist. These foundations are providing a scaffolding within which, and around which, new conceptualisations and new practices appropriate to our shifting harmscapes are emerging. What the lines of flight we have identified suggest is that the contours of these emerging criminologies are likely to take us in directions beyond our present imaginings and in doing so likely to move criminology in decidedly uncomfortable directions, potentially far beyond its established parameters. Whether this will lead to the demise of criminology, as we note below, or whether this will lead to a new beginning remains to be seen. What seems, to us, to be beyond doubt is that in the face of emerging harmscapes criminology, along with much else, will be very different. To borrow words from Naomi Klein (2014), 'this changes everything'.

While the lines of flight we have canvassed here have not been at the core of criminology, they have pushed at the boundaries, and have sat, determinedly, on its outskirts - shaping edges that invite us to traverse new terrains. As we have noted, a sticking point in engaging with new worlds is the question of how far criminologists can push the boundaries of what is considered a traditional focus of criminology, before they push themselves out of criminology altogether? When confronting these new worlds, do criminologists abandon or 'abolish' criminology, if it doesn't keep pace with these developments? Or do criminologists attempt to change it from within? Or do we perhaps, as Shearing (1989) suggest, 'decriminalise criminology', while maintaining the term as a metonym. 
The existence, and effects, of these new worlds are having, and will have, profound implications for criminology - in terms of how we engage with new harms, how we engage with novel ways of thinking that have often been ignored, or ousted to the periphery, and what new theoretical and analytical tools we may need to create (or borrow from elsewhere) as we engage with shifting realities. At the start of this paper, we referred to Taylor, Walton and Young's (2013) New Criminology. What we have been suggesting implicitly, in our brief overview of lines of flight that are responding to new worlds, is that what perhaps is needed is a new, new criminology.

Given the lines of flight we have canvassed, perhaps we already have a new, new criminology(ies) inspired by these new worlds, and that what is needed is a recognition of, and a building on, these foundations. The challenge then is not to start from scratch but to be honest and reflexive about criminology's foundational influences, and its imperialist roots and to reshape it from within - if we choose to. As Richard Sparks (2019, p. 24) reminds us this can be a constructive time for criminology as it 'tends to be at its most creative when its defences are down, and when it reaches outside for refreshment and orientation'. To continue to take inspiration from Sparks (2019, p. 24-25), in these moments 'we can think much less about criminology's internal squabbles and more about its capacity to engage with and participate in other conversations.'

\section{Note}

1. For a pithy and amusing statement, see Latour's essay, written under a pseudonym, entitled 'The Sociology of a Door-Closer' (Johnson, 1988).

\section{References}

Agozino, B. (2003). Counter-Colonial Criminology: A Critique of Imperialist Reason. Pluto.

Agozino, B. (2004). Imperialism, crime and criminology: Towards the decolonisation of criminology. Crime, Law \& Social Change, 41, 343-358.

Agozino, B. (2020). Fuck the law: decolonizing nomophilitis with the discourse of love. Globalizations, 17(7), 1091-1103. 
Alemika, E. (2020). Reflections on criminology in Africa. Acta Criminologica: African Journal of Criminology \& Victimology, 33(2), 1-11.

Attenborough, D. (2020) A Life on Our Planet: My Witness Statement and a Vision for the Future. Penguin.

Baker, B. (2008). Multi-choice policing in Africa. Nordiska Afrikainstitutet.

Berg, J. \& Shearing, C. (2018). Governing-through-Harm and Public Goods Policing. The Annals of the American Academy of Political and Social Sciences, 679(1),72-85.

Berg, J. \& Shearing, C. (Forthcoming). Advanced Introduction to Criminology, Elgar.

Bonneuil, C. \& Fressoz, J-B. (2017). The Shock of the Anthropocene: The Earth, History and Us. Verso.

Braithwaite, J. (2000). The New Regulatory State and the Transformation of Criminology. British Journal of Criminology, 40, 222-238.

Brisman, A. \& South, N. (2018). Green Criminology and Environmental Crimes and Harms. Sociology Compass, 13(1), 1-12.

Brodeur, J-P. (2010). The policing web. Oxford University Press.

Button, M. (2020). The 'New' Private Security Industry, the Private Policing of Cyberspace and the Regulatory Questions. Journal of Contemporary Criminal Justice, 36(1), 39-55.

Carbon Market Institute. (2020). Carbon Farming and Bushfire Recovery National Workshop Report. Presentation (NND.001.00877) to the Australian Royal Commission into National Disaster Arrangements. https://naturaldisaster.royalcommission.gov.au/system/files/submission/NND.001.00877.pdf

Carrington, K., Hogg, R. \& Sozzo, M. (2016). Southern Criminology. British Journal of Criminology, 56(1),1-20. 
Carrington, K., Hogg, R., Scott, J. \& Sozzo, M. (Eds) (2018). The Palgrave Handbook of Criminology and the Global South. Palgrave Macmillan.

Carrington, K., Dixon, B., Fonseca, D., Goyes, D., Liu, J. \& Zysman, D. (2019).

Criminologies of the Global South: Critical Reflections. Critical Criminology, 27(1),163-189.

Carrington, K., Hogg, R., Scott, J., Sozzo, M. \& Walters, R. (2019). Southern Criminology. Routledge.

Castells, M. (1999). Grassrooting the space of flows. Urban Geography, 20(4), 294-302.

Chang, L., Zhong, L. \& Grabosky, P. (2018). Citizen Co-production of Cyber Security: Selfhelp, Vigilantes, and Cybercrime. Regulation and Governance, 12, 101-114.

Chukwuma, I. (2011). Nigeria: Social structure, criminal justice and criminology. In C. Smith, S. Zhang \& R. Barberet (Eds), Routledge Handbook of International Criminology (pp. 463-474). Routledge.

Clarke, Ronald V. (Ed) (1997). Situational Crime Prevention: Successful Case Studies. Harrow and Heston.

Clear, T. (2007). Imprisoning communities: How mass incarceration makes disadvantaged neighborhoods worse. Oxford University Press.

Clear, T. (2011). A Private Sector, Incentives-Based Model for Justice Reinvestment. Criminology and Public Policy, 10(3), 585-608.

Crawford, A., Lister, S., Blackburn, S. \& Burnett, J. (2005). Plural policing: the mixed economy of visible patrols in England and Wales. Policy Press.

Cunneen, C. (2011). Postcolonial Perspectives for Criminology. In M. Bosworth \& C. Hoyle (Eds), What is Criminology? (pp. 249-266). Oxford University Press. 
Cunneen, C. \& Tauri, T. (2016). Indigenous criminology. Policy Press.

Deckert, A. (2014). Neo-colonial criminology: quantifying silence. African Journal of Criminology and Justice Studies, 8(1), 39-60.

Del Olmo, R. (1999). The Development of Criminology in Latin America. Social Justice, 26(2), 19-45.

Dixon, B. (2001). Exclusive Societies: Towards a Critical Criminology of Post-Apartheid South Africa. Society in Transition, 32(2), 205-227.

Dixon, B. (2004). In Search of Interactive Globalisation: Critical Criminology in South Africa's Transition. Crime, Law \& Social Change, 41, 359-384.

Drahos, P. (2021). Survival Governance. Oxford University Press.

Dupont, B. (2018). The Global Anti-cybercrime Network: Mapping the Polycentric Regulation of Online Harms. In L. Chang \& R. Brewer (Eds), Criminal Justice and Regulation Revisited: Essays in Honour of Peter Grabosky (pp. 163-185). Routledge.

Ebbe, O. (2011). Ghana: The state of criminology in a changing society. In C. Smith, S. Zhang \& R. Barberet (Eds), Routledge Handbook of International Criminology (pp. 390399). Routledge.

Escobar, G. (2011). Colombia: Crime trends, criminal justice, and criminology in a society in turmoil. In C. Smith, S. Zhang \& R. Barberet (Eds), Routledge Handbook of International Criminology (pp. 360-375). Routledge.

Felson, M. 1998. Crime and Everyday Life (2nd ed). Pine Forge Press.

Floyd, R. (2015). Environmental Security and the case against rethinking criminology as 'security-ology'. Criminology and Criminal Justice, 15(3), 277-282. 
Galanter, M. (1981). Justice in Many Rooms: Courts, Private Ordering, and Indigenous Law. Journal of Legal Pluralism, 19, 1-48.

Garland, D. (1996). The limits of the sovereign state: strategies of crime control in contemporary society. British Journal of Criminology, 36(4),445-471.

Garland, D. \& Sparks, R. (2000). Criminology, Social Theory and the Challenge of our Times. British Journal of Criminology, 40(2), 189-204.

Goyes, D. (2019). Green Southern Criminology: Science against Ecological Discrimination. Emerald Publishing.

Greenberg, A. (2019). Sandworm: A new era of cyberwar and the hunt for the Kremlin's most dangerous hackers. Penguin Random House.

Harrington, C. \& Shearing, C. (2017). Security in the Anthropocene: Reflections on Safety and Care. Transcript.

Haugh, T. (2015). Overcriminalization's New Harm Paradigm. Vanderbilt Law Review, $68(5), 1191-1241$.

Heskia, J. (2011). Chile: A criminological approach. In C. Smith, S. Zhang \& R. Barberet (Eds), Routledge Handbook of International Criminology (pp. 349-359). Routledge.

Hillyard, P. (2004). Beyond Criminology: Taking Harm Seriously. Pluto Press.

Hillyard, P. \& Tombs, S. (2007). From 'crime' to social harm? Crime Law and Social Change, 48, 9-25.

Jewkes, Y. (2003). Policing Cybercrime. In T. Newburn (Ed), Handbook of Policing (pp. 501-524). Willan. 
Johnson, J. (1988). Mixing Humans and Nonhumans Together: The Sociology of a DoorCloser. Social Problems, 35(3), Special Issue: The Sociology of Science and Technology, 298-310.

Jones, T.\& Newburn, T. (Eds). (2006). Plural Policing: A Comparative Perspective. Routledge.

Juarez, M.A. \& Solares, V.M. (2011). Mexico: The state of criminology and public safety. In C. Smith, S. Zhang \& R. Barberet (Eds), Routledge Handbook of International Criminology (pp. 452-562). Routledge.

Kelling, G. (1991). Crime and Metaphor: Toward a New Concept of Policing. City Journal, Autumn, 7-12.

Kennedy, D. \& Klare, K. (1984). A bibliography of critical legal studies. Yale Law Journal, 94,641 .

Kitossa, T. (2012). Criminology and Colonialism: Counter Colonial Criminology and the Canadian Context. The Journal of Pan African Studies, 4(10), 204-226.

Kitossa, T. (2020). Authoritarian Criminology and Racist Statecraft: Rationalizations for Racial Profiling, Carding and Legibilizing the Herd. Decolonization of Criminology and Justice, 2(1), 5-36.

Klein, N. (2014). This Changes Everything: Capitalism vs. the Climate. Allen Lane.

Kuhn, T. (1962/2012). The Structure of Scientific Revolution. University of Chicago Press.

Latour, B. (1993). We Have Never Been Modern. Harvard University Press.

Lee, M., \& Laidler, K. J. (2013). Doing criminology from the periphery: Crime and punishment in Asia. Theoretical Criminology, 17(2), 141-157. 
Liu, J. (2009). Asian Criminology - Challenges, Opportunities and Directions. Asian Journal of Criminology, 4(1), 1-9.

Liu, J. (2017). The Asian Criminological Paradigm and How it Links Global North and South: Combining an Extended Conceptual Toolbox from the North with Innovative Asian Contexts. International Journal for Crime, Justice and Social Democracy, 6(1), 73-87.

Liu, J., Hebenton, B. \& Jou, S. (2013). Handbook of Asian criminology. Springer, pp. 1-7.

Liu, J., Travers, M. \& Chang, L. (Eds) (2017). Comparative Criminology in Asia. Springer.

Loader, I. (2000). Plural policing and democratic governance. Social \& Legal Studies, 9(3), 323-345.

Lovelock, J. (2019). Novacene: The Coming Age of Hyperintelligence. Penguin.

Lynch, M. (1990). The Greening of Criminology: a perspective on the 1990s. The Critical Criminologist, 2(3), 11-12.

Mazerolle, L. \& Ransley, J. (2005) Third Party Policing. Cambridge.

Macauley, S. (1986). Private Government. In L. Lipson \& S. Wheeler (Eds) Law and the Social Sciences (pp. 445-518). Russell Sage Foundation.

Medina, J. (2011). Doing criminology in the 'semi-periphery' and the 'periphery'. In C. Smith, S. Zhang \& R. Barberet (Eds), Routledge Handbook of International Criminology (pp. 13-24). Routledge.

Moosavi, L. (2019). Decolonising Criminology: Syed Hussein Alatas on Crimes of the Powerful. Critical Criminology, 27, 229-242.

Mullins, G. (2020). Emergency Leaders for Climate Action. Presentation (NND.6001.00269) to the Australian Royal Commission into National Disaster Arrangements. https://naturaldisaster.royalcommission.gov.au/system/files/submission/NND 
$.600 .00269 . p d f$

Ouassini, N. \& Ouassini, A. (2020). Criminology in the Arab World: Misconceptions, Nuances and Future Prospects. British Journal of Criminology, 60, 519-536.

Pemberton, S. (2007). Social harm future(s): Exploring the potential of the social harm approach. Crime Law and Social Change, 48, 27-41.

Radzinowicz, L. (1956). A History of English Criminal Law and its Administration from 1750: The Clash between Private Initiative and Public Interest in the Enforcement of the Law. Steven and Sons.

Rodrigues, C.D. (2011). Brazil: The state of criminology. In C. Smith, S. Zhang \& R. Barberet (Eds), Routledge Handbook of International Criminology (pp. 313-323).Routledge.

Ruggiero, V. (2010). Penal Abolitionism. Oxford University Press.

Schulte-Bockholt, A. (2012). Latin American critical criminology. In W. DeKeseredy \& M. Dragiewicz (Eds), Routledge Handbook of Critical Criminology (pp. 70-86). Routledge.

Shearing, C. (1989). Decriminalizing Criminology: Reflections on the Literal and Tropological Meaning of the Term. Canadian Journal of Criminology, 31(2), 169-178.

Shearing, C. (2006). Reflections on the Refusal to Acknowledge Private Governments. In J. Wood \& B. Dupont (Eds), Democracy, Society and the Governance of Security (pp. 1132). Cambridge University Press.

Shearing, C. (2015). Criminology and the Anthropocene. Criminology \& Criminal Justice, 15(3), 255-269.

Simon, J. (2007). Governing through Crime: How the War on Crime Transformed American Democracy and Created a Culture of Fear. Oxford University Press. 
Smith, D. (1987). The Everyday World as Problematic: A Feminist Sociology. Northeastern University Press.

South, N. (1998). A Green Field for Criminology? A proposal for a perspective. Theoretical Criminology, 2(2), 211-234.

Sparks, R. (2019). Beyond the Rendez-vous: Criminology, Critique, Connection. Honorary Doctorate Prof. dr. Richard Sparks in honour of the 90th anniversary of criminology (19292019) in Leuven, 25 April.

Spitzer, S. \& Scull, A. (1997). Privatization and Capitalist Development: The Case of the Private Police. Social Problems, 25(1), 18-29.

Stenning, P. (2009). Governance and accountability in a plural policing environment - the story so far. Policing, 3(1), 22-33.

Tauri, J. (2017). Imagining an Indigenous Criminological Future. In A. Deckert \& R. Sarre (Eds), The Palgrave Handbook of Australian and New Zealand Criminology, Crime and Justice (pp. 769-783). Palgrave Macmillan.

Taylor, I., Walton, P. \& Young, J. (2013). The New Criminology for a Social Theory of Deviance. Routledge

Tombs, S. (2018). For Pragmatism and Politics: Crime, Social Harm and Zemiology. In A. Boukli \& J. Kotzé (Eds), Zemiology: Reconnecting Crime and Social Harm (pp. 11-31). Palgrave.

Van der Wagen, W. \& Pieters, W. (2015). From Cybercrime to Cyborg Crime: Botnets as Hybrid Criminal Actor-Networks. British Journal of Criminology, 55, 578-595.

Van der Wagen, W., \& Pieters, W. (2020). The hybrid victim: Re-conceptualizing high-tech cyber victimization through actor-network theory. European Journal of Criminology, 17(4), $480-497$. 
Van Sluis, A., Marks, P. \& Bekkers, V. (2011). 'Nodal Policing in the Netherlands: Strategic and Normative Considerations on an Evolving Practice'. Policing, 5(4), 365-371.

Van Zyl Smit, D. (1999). Criminological ideas and the South African transition. The British Journal of Criminology, 39(2), 198-215.

Valverde, M. (2013). Time and Space in the Governance of Crime and Security. Lecture, Leeds University, October 16.

Valverde, M. (2014). Studying the governance of crime and security: Space, time and jurisdiction. Criminology and Criminal Justice, 14(4), 379-391.

Wall, D. (2007). Policing Cybercrimes: Situating the Public Police in Networks of Security within Cyberspace. Police Practice and Research, 8(2), 183-205.

Wallace-Wells, D. (2019). The Uninhabitable Earth: A Story of the Future. Allan Lane.

White, J. B. (1984). When Words Lose their Meanings: Constitutions and Reconstructions of Language, Character, and Community. University of Chicago Press.

White, R. (2011). Transnational Environmental Crime: Toward an eco-global criminology. Routledge.

White, R. (2018a). Ecocide and the Carbon Crimes of the Powerful. The University of Tasmania Law Review, 37(2), 95-115.

White, R. (2018). Climate Change Criminology. Bristol University Press.

White, R. \& Heckenberg, D. (2014). Green Criminology: an introduction to the study of environmental harm. Routledge. 